\title{
KAJIAN TINGKAT PEMAKAIAN HELM DAN KEPARAHAN KECELAKAAN PADA ANAK DI KOTA BANDUNG
}

\section{Study of the Level of Children Accidents Severity and Helmet Use in Bandung City}

\author{
Aine Kusumawati \\ Fak. Teknik Sipil dan Lingkungan \\ Institut Teknologi Bandung \\ Jl. Ganesa No. 10, Kota Bandung \\ Jawa Barat \\ aine@ftsl.itb.ac.id
}

\author{
Estiara Ellizar \\ Fak. Teknik Sipil dan Lingkungan \\ Institut Teknologi Bandung \\ Jl. Ganesa No. 10, Kota Bandung \\ Jawa Barat \\ estiaraellizar@yahoo.com
}

\author{
Hamsyin Rivai \\ Fak. Teknik Sipil \& Lingkungan \\ Institut Teknologi Bandung \\ J1. Ganesa No. 10, Kota Bandung \\ Jawa Barat
}

\begin{abstract}
Majority of crash and crash casualty in Bandung involved motorcyclists. This research aims to find out relation between helmet wearing and crash severity in adult and young motorcyclists. The result indicates the higher the rate of helmet usage relates to the lower risk of being killed or injured in a motorcycle crash. Young motorcycle passengers have 3 times higher risk of being killed and 2.2 times higher risk of being injured compared to adult motorcycle passengers as the rate of wearing helmet correctly in young motorcycle passengers is lower than that of adult motorcycle passengers. Meanwhile, young motorcycle drivers have 0.46 times lower risk of being killed and 0.67 times lower risk of being injured compared to adut motorcycle drivers as the rate of wearing helmet correctly in young motorcycle drivers is higher than that of adult motorcycle drivers.
\end{abstract}

Keywords: helmet wearing rate, crash severity, motorcyclist

\begin{abstract}
Abstrak
Mayoritas kecelakaan dan korban kecelakaan di Kota Bandung melibatkan pesepeda motor. Penelitian ini bertujuan untuk mengetahui hubungan antara pemakaian helm terhadap keparahan kecelakaan yang melibatkan pesepeda motor dewasa dan anak-anak di Kota Bandung. Hasil penelitian mengindikasikan semakin tinggi tingkat pemakaian helm secara benar berhubungan dengan semakin rendahnya risiko mengalami kematian dan luka-luka dalam suatu kecelakaan yang melibatkan pesepeda motor. Penumpang sepeda motor anak-anak memiliki risiko meninggal dunia 3 kali lebih tinggi dan risiko luka-luka 2,2 kali lebih tinggi apabila mengalami kecelakaan dibanding penumpang dewasa karena tingkat pemakaian helm secara benar yang lebih rendah pada penumpang sepeda motor anak-anak. Sementara pengendara sepeda motor anak-anak memiliki risiko meninggal dunia 0,46 kali lebih rendah dan risiko luka-luka 0,67 kali lebih rendah apabila mengalami kecelakaan dibanding penumpang sepeda motor dewasa karena tingkat pemakaian helm secara benar yang lebih tinggi pada pengendara sepeda motor anak-anak.
\end{abstract}

Kata kunci: tingkat pemakaian helm, keparahan kecelakaan, pesepeda motor

\section{PENDAHULUAN}

Pesepeda motor merupakan kelompok pengguna jalan yang rentan mengalami kecelakaan, dan jika terlibat kecelakaan pesepeda motor memiliki kemungkinan yang besar untuk mengalami luka parah, bahkan kematian. Lin dan Kraus (2009) menyebutkan bahwa pesepeda motor memiliki kemungkinan lebih dari 30 kali lipat untuk mati dalam suatu kecelakaan dibanding penumpang kendaraan roda empat. Data dari WHO (2016) menunjukkan bahwa hampir separuh dari kematian akibat kecelakaan lalu lintas di dunia melibatkan pejalan kaki, pesepeda, dan pesepeda motor. Bahkan untuk level Asia 
Tenggara, mayoritas kematian akibat kecelakaan melibatkan pesepeda motor, hal ini bukan saja karena populasi sepeda motor yang tinggi di Asia Tenggara namun juga karena adanya risiko yang tinggi bagi pesepeda motor untuk terlibat kecelakaan yang menyebabkan kematian.

Mayoritas kecelakaan dan korban kecelakaan di Kota Bandung melibatkan pesepeda motor (Pemerintah Kota Bandung, 2017 dan 2018). Pada tahun 2015-2016, 74\% kecelakaan lalu lintas melibatkan sepeda motor, dan sebanyak $71 \%$ kematian akibat kecelakaan lalu lintas dialami oleh pesepeda motor, baik sebagai pengendara (57\%) maupun penumpang (14\%). Sementara pada tahun 2017 proporsinya tidak berbeda jauh; 68\% kecelakaan lalu lintas melibatkan sepeda motor, dan sebanyak 69\% kematian akibat kecelakaan lalu lintas dialami oleh pesepeda motor, baik sebagai pengendara (57\%) maupun penumpang (12\%). Mayoritas cedera dan kematian pesepeda motor dialami oleh pesepeda motor yang berumur di antara $15-24$ tahun.

Umumnya, kematian pesepeda motor tersebut disebabkan oleh luka di kepala (Dandona et al., 2006; Servadei et al., 2003). Banyak penelitian yang telah menunjukkan bahwa pemakaian helm dapat mengurangi keparahan luka di kepala dan tulang belakang dan kematian pada kecelakaan sepeda motor (Kelly et al., 1991; Shankar et al., 1992). Abbas et al. (2012) menyimpulkan bahwa faktor yang paling berpengaruh terhadap kematian sepeda motor adalah tidak menggunakan helm. Setiap peningkatan $10 \%$ pada tingkat penggunaan helm dapat mengurangi tingkat kematian sebesar satu per satu juta populasi setiap tahunnya. WHO (2016) menyebutkan bahwa penggunaan helm secara benar (sesuai standar dan dikencangkan) dapat mengurangi risiko kematian akibat kecelakaan sebesar $40 \%$ dan risiko luka berat sekitar $70 \%$ pada pesepeda motor.

Namun studi observasional yang dilakukan oleh John Hopkins International Injury Research Unit (JHIIRU) bersama Universitas Padjadjaran (UNPAD) dalam kurun waktu 2015 - 2017 (BIGRS, 2017) menyimpulkan bahwa tingkat penggunaan helm secara tepat di kalangan pesepeda motor (pengendara dan penumpang) di Kota Bandung masih cukup rendah. Untuk pengendara sepeda motor anak-anak (usia kurang dari 18 tahun), tingkat pemakaian helm secara benar hanya sebesar 50,8\% - 62,6\%, sementara untuk pengendara sepeda motor dewasa (usia di atas 18 tahun) sebesar 61,2\% - 77,6\%. Untuk penumpang sepeda motor, hanya $13,3 \%$ - 23,8\% penumpang sepeda motor anak-anak dan $43,1 \%$ $61,4 \%$ penumpang sepeda motor dewasa yang telah menggunakan helm secara benar.

Penelitian ini bertujuan untuk mengetahui hubungan antara pemakaian helm dengan keparahan kecelakaan yang melibatkan pesepeda motor dewasa dan anak-anak di Kota Bandung. Data yang digunakan adalah data kecelakaan lalu lintas yang bersumber dari Integrated Road Safety Management System (IRSMS) di Kota Bandung 2015 - 2017. Hasil dari penelitian ini diharapkan dapat membantu Kepolisian Lalu Lintas dan pemangku kepentingan lainnya untuk memperketat standar/peraturan penggunaan helm bagi para pengguna sepeda motor, khususnya anak-anak, dan memperketat penegakan hukum di bidang pemakaian helm secara benar.

\section{METODOLOGI}

Penelitian ini menggunakan metoda statistik deskriptif. Data tingkat pemakaian helm dikumpulkan dari survei pengamatan lapangan di 30 titik ruas jalan di pusat Kota Bandung. Survey dilakukan selama satu jam pada perioda waktu berangkat sekolah (06.00 
- 07.00) dan perioda waktu pulang sekolah (10.30 - 11.30 atau 11.30 - 12.30). Pengamatan dilakukan terhadap pemakaian helm dari obyek survey (sampel). Pemakaian helm dibedakan menjadi memakai helm secara benar (helm sesuai standar dan dikencangkan), memakai helm tetapi tidak benar (helm tidak sesuai standar atau tidak dikencangkan), dan tidak memakai helm. Sampel pada penelitian ini adalah seluruh pesepeda motor anak-anak yang diamati lewat melintasi titik pengamatan selama waktu survey. Sampel dibedakan lebih lanjut menjadi pengendara anak-anak dan penumpang anak-anak. Definisi anak-anak yang digunakan pada penelitian ini adalah setiap orang yang berusia di bawah 18 tahun. Secara lebih detail, penelitian ini mengkategorikan pesepeda motor anak-anak sebagai pengendara usia SMA (16-18 tahun), penumpang usia SMA (1618 tahun), penumpang usia SMP (13-15 tahun), penumpang usia SD (6-12 tahun), dan penumpang usia TK/Balita (di bawah 6 tahun).

Data keparahan korban kecelakaan sepeda motor berasal dari data kecelakaan lalu lintas IRSMS Kota Bandung 2016 - 2017. Keparahan pesepeda motor yang menjadi korban kecelakaan dibedakan menjadi meninggal dunia dan luka-luka (luka berat dan luka ringan), yang lebih lanjut juga dianalisis untuk lima kategori pesepeda motor anak-anak seperti telah dijabarkan sebelumnya.

\section{HASIL}

\section{Karakteristik Korban Kecelakaan Sepeda Motor di Kota Bandung}

Dalam kurun waktu 2016-2017, jumlah pesepeda motor yang menjadi korban meninggal dunia dan luka-luka akibat kecelakaan di Kota Bandung mengalami peningkatan yang cukup signifikan, yaitu sebesar $46 \%$, baik sebagai pengendara maupun penumpang. Ditinjau dari penggunaan alat keselamatan (helm), proporsi korban kecelakaan sepeda motor yang memakai helm sebesar 43\% dan yang tidak memakai helm sebesar 1\%, sisanya sebesar 56\% tidak diketahui apakah memakai helm atau tidak (sesuai yang ditunjukkan pada Gambar 1 dan Tabel 1). Sayangnya, tidak ada informasi mengenai kriteria pemakaian helm secara benar dalam data yang diperoleh.

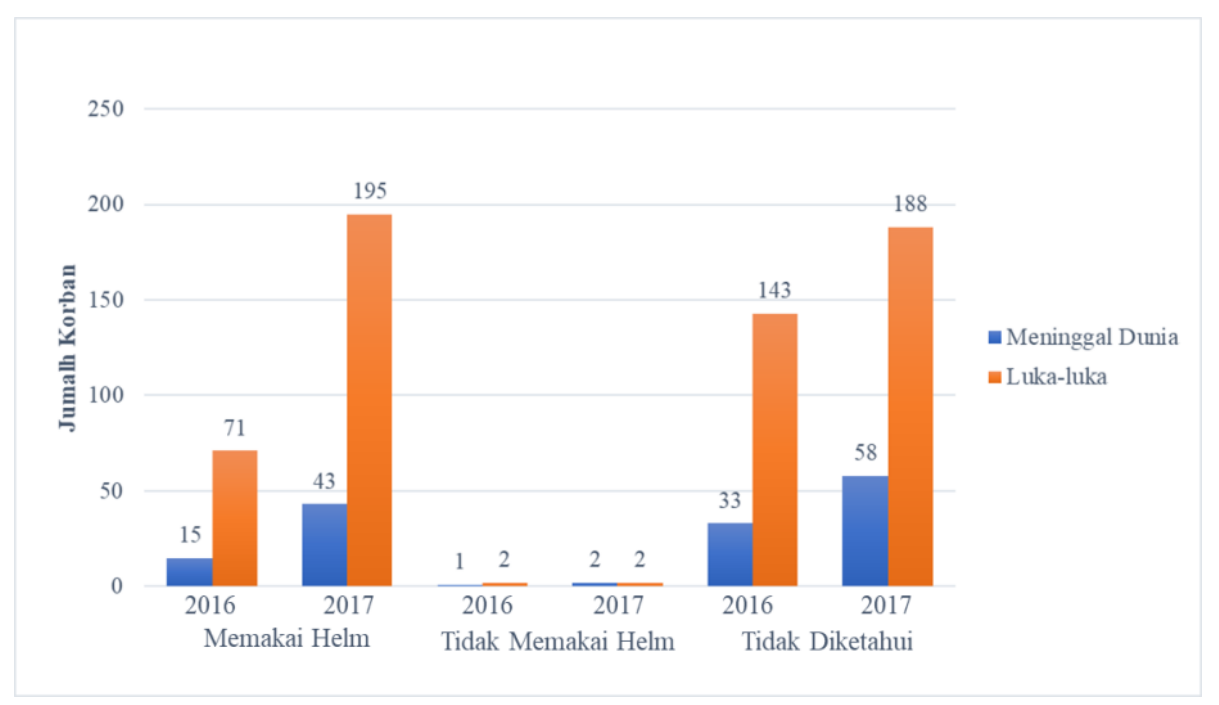

Gambar 1. Jumlah pesepeda motor korban kecelakaan berdasarkan pemakaian helm di Kota Bandung 
Tabel 1. Proporsi keparahan korban kecelakaan sepeda motor berdasarkan pemakaian helm di Kota Bandung

\begin{tabular}{ccccccc}
\hline \multirow{2}{*}{$\begin{array}{c}\text { Keparahan Korban } \\
\text { Kecelakaan }\end{array}$} & \multicolumn{2}{c}{ Memakai Helm } & \multicolumn{2}{c}{ Tidak Memakai Helm } & \multicolumn{2}{c}{ Tidak Diketahui } \\
\cline { 2 - 7 } & $\mathbf{2 0 1 6}$ & $\mathbf{2 0 1 7}$ & $\mathbf{2 0 1 6}$ & $\mathbf{2 0 1 7}$ & $\mathbf{2 0 1 6}$ & $\mathbf{2 0 1 7}$ \\
\hline Meninggal Dunia & 15 & 43 & 1 & 2 & 33 & 58 \\
\hline Luka-luka & 71 & 195 & 2 & 2 & 143 & 188 \\
\hline Total & 86 & 238 & 3 & 4 & 176 & 246 \\
\hline \% Pemakaian Helm & & $43 \%$ & & & $1 \%$ & $56 \%$ \\
\hline
\end{tabular}

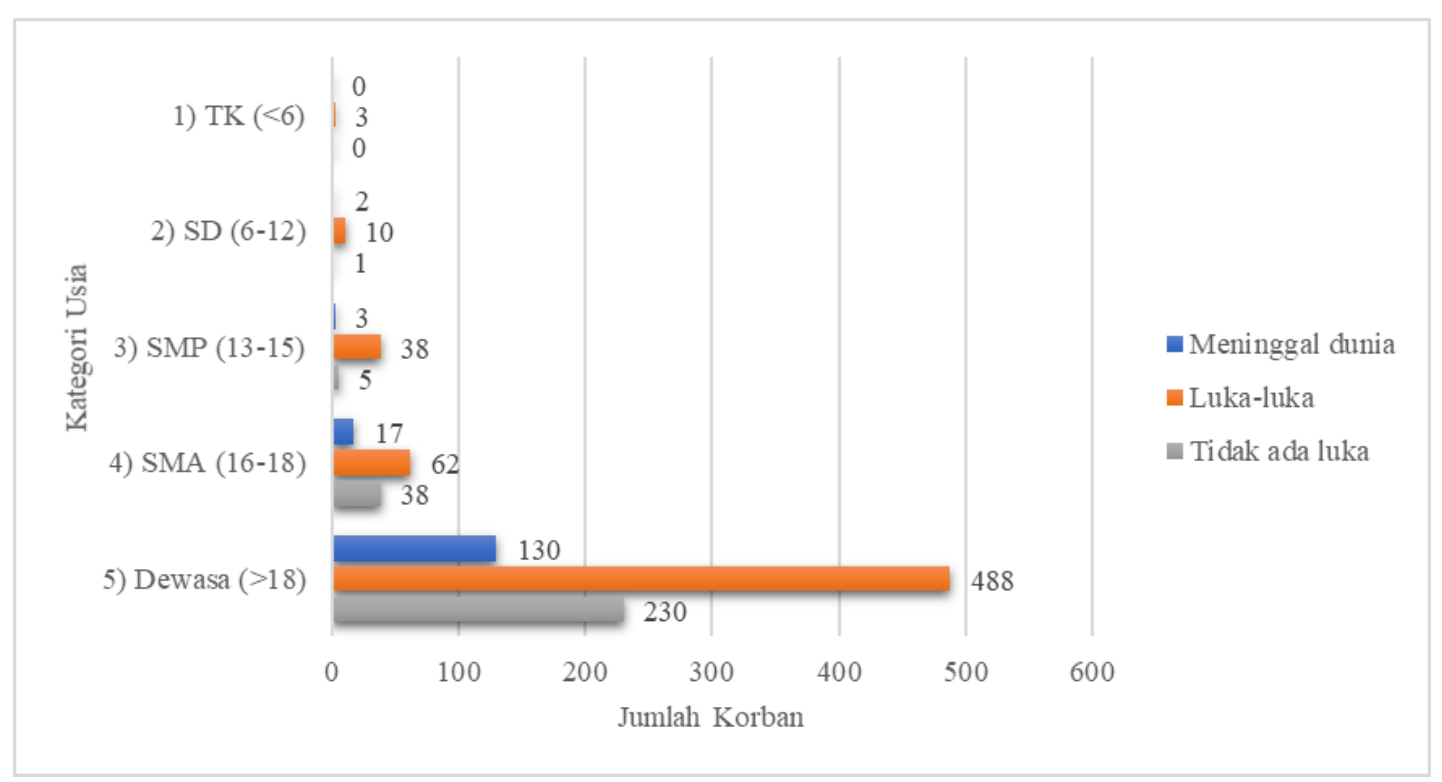

Gambar 2. Kecelakaan sepeda motor berdasarkan kategori usia di Kota Bandung

Hasil analisis di atas menunjukkan bahwa sebagian besar korban kecelakaan sepeda motor masih didominasi oleh usia Dewasa (lebih dari 18 tahun) dibandingkan usia Anak (kurang dari 18 tahun). Bila data tersebut dikategorikan lagi menjadi pengendara dan penumpang sepeda motor usia anak dan dewasa maka hasilnya adalah sesuai dengan yang ditampilkan pada Tabel 2.

Tabel 2. Kecelakaan sepeda motor berdasarkan kategori usia di Kota Bandung

\begin{tabular}{ccccccc}
\hline \multirow{2}{*}{ Kategori Usia } & \multicolumn{2}{c}{ Meninggal Dunia } & \multicolumn{2}{c}{ Luka-luka } & \multicolumn{2}{c}{ Tidak Ada luka } \\
\cline { 2 - 7 } & Pengendara & Penumpang & Pengendara & Penumpang & Pengendara & Penumpang \\
\hline TK/Balita & 0 & 0 & 0 & 3 & 0 & 0 \\
SD & 0 & 2 & 1 & 9 & 1 & 0 \\
SMP & 1 & 2 & 13 & 25 & 5 & 0 \\
SMA & 10 & 7 & 36 & 26 & 38 & 0 \\
\hline Dewasa & 110 & 20 & 353 & 135 & 228 & 2 \\
\hline Total & 121 & 31 & 403 & 198 & 272 & 2 \\
\hline
\end{tabular}


Dari tabel di atas dapat dilihat ternyata terdapat 21 anak-anak yang masih berusia dibawah 15 tahun (kategori SD dan SMP) yang menjadi pengendara sepeda motor meskipun belum cukup umur.

Analisis kemudian dilanjutkan untuk melihat perbandingan antara keparahan kecelakaan yang dialami anak-anak dan dewasa. Analisis dilakukan dengan membandingkan setiap jumlah korban untuk masing-masing tingkat keparahan (meninggal dunia (MD), luka-luka (LL) dan tidak ada luka (TL)) terhadap total korban kecelakaan sepeda motor pada masingmasing kategori usia dengan menggunakan Persamaan 1.

$$
R=\frac{(M D / L L / T L)_{1,2}}{M D+L L+T L_{1,2}}
$$

$$
\begin{aligned}
\text { Dimana: } \mathrm{R}= & \begin{array}{l}
\text { tingkat keparahan kecelakaan } \\
\text { (dihitung untuk pengendara dan penumpang) }
\end{array} \\
\mathrm{MD} / \mathrm{LL} / \mathrm{TL}= & \mathrm{MD}: \text { Meninggal dunia; } \\
& \mathrm{LL}: \text { Luka-luka; } \\
& \mathrm{TL}: \text { Tidak ada luka } \\
& \text { (digunakan salah satu dalam perhitungan) } \\
= & 1 \quad: \text { : Anak-anak; } \\
& 2 \quad: \text { Dewasa } \\
& \text { (digunakan salah satu dalam perhitungan) }
\end{aligned}
$$

Adapun hasil perhitungan menggunakan Persamaan 1 dirangkum dalam Tabel 3 berikut.

Tabel 3. Tingkat keparahan kecelakaan sepeda motor berdasarkan kategori usia di Kota Bandung

\begin{tabular}{cccccccc}
\hline \multirow{2}{*}{ Kategori Usia } & \multicolumn{2}{c}{ Meninggal Dunia } & \multicolumn{2}{c}{ Luka-luka } & \multicolumn{2}{c}{ Tidak Ada luka } \\
\cline { 2 - 7 } & Pengendara & Penumpang & Pengendara & Penumpang & Pengendara & Penumpang \\
\hline Usia Anak & 0,06 & 0,06 & 0,28 & 0,35 & 0,25 & 0,00 \\
\hline Usia Dewasa & 0,13 & 0,02 & 0,42 & 0,16 & 0,27 & 0,00 \\
\hline
\end{tabular}

Hasil perhitungan pada tabel tersebut menunjukkan bahwa meskipun sebagian besar korban didominasi oleh usia dewasa, namun tingkat keparahan kecelakaan pada anak-anak lebih besar dari dewasa, khususnya anak-anak sebagai penumpang sepeda motor. Untuk korban meninggal dunia, keparahan pada penumpang anak-anak sebesar 0,06 yang lebih besar dari keparahan penumpang dewasa sebesar 0,02. Hal yang sama ditunjukan pula untuk korban luka-luka, dimana keparahan pada penumpang anak-anak sebesar 0,35 yang lebih besar dari dua kali lipat keparahan penumpang dewasa sebesar 0,16. Hal ini menunjukkan bahwa jika anak-anak terlibat dalam kecelakaan sepeda motor akan mengalami kemungkinan cedera yang lebih serius dibandingkan dewasa.

\section{Tingkat Pemakaian Helm pada Pesepeda Motor Anak-Anak di Kota Bandung}

Hasil survey pemakaian helm pada pesepeda motor (pengendara dan penumpang sepeda motor) anak-anak di Kota Bandung saat jam berangkat sekolah dan jam pulang sekolah ditampilkan pada Gambar 3 dan Gambar 4 berikut, masing-masing secara berturutan untuk kategori pengendara sepeda motor anak-anak dan penumpang sepeda motor anak-anak. 


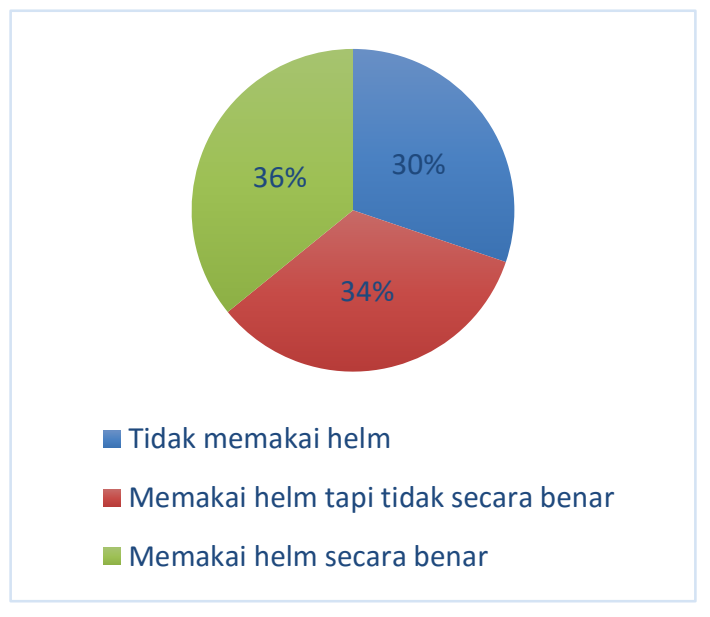

Jam Berangkat Sekolah

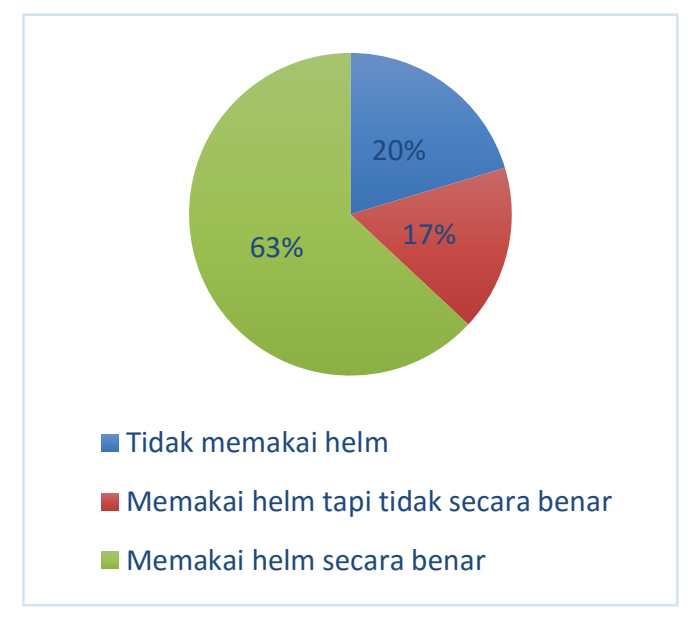

Jam Pulang Sekolah

Gambar 3. Tingkat pemakaian helm pada pesepeda motor anak-anak saat jam berangkat sekolah dan jam pulang sekolah

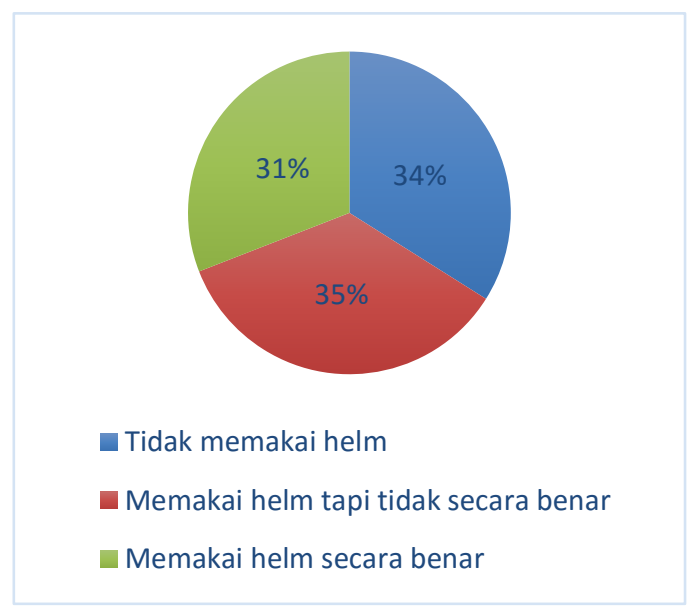

Jam Berangkat Sekolah

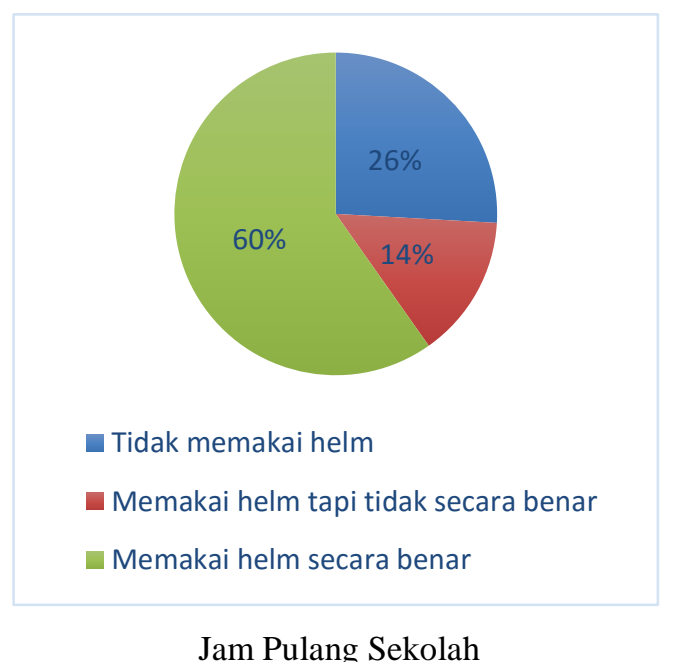

Jam Pulang Sekolah

Gambar 4. Tingkat pemakaian helm pada penumpang sepeda motor anak-anak saat jam berangkat sekolah dan jam pulang sekolah

Dari kedua gambar tersebut dapat dilihat ternyata secara umum tingkat pemakaian helm pada pengendara sepeda motor anak-anak saat jam berangkat sekolah masih cukup rendah, hanya sekitar 36\% dibanding dengan 63\% saat jam pulang sekolah. Apabila hanya ditinjau untuk kategori penumpang anak-anak saja, maka tingkat pemakaian helm lebih rendah lagi, yaitu sebesar 31\% saat jam berangkat sekolah dan 60\% saat jam pulang sekolah.

Apabila data tersebut didetailkan lagi berdasarkan kategori usia SMA, SMP, SD, dan TK/Balita, maka hasilnya seperti tertera pada Tabel 4 dan Tabel 5, masing-masing untuk saat jam berangkat sekolah dan jam pulang sekolah. 
Tabel 4. Jumlah dan proporsi pemakaian helm pada pesepeda motor anak-anak saat jam berangkat sekolah

\begin{tabular}{|c|c|c|c|c|c|c|c|}
\hline \multirow{2}{*}{ Golongan } & \multirow{2}{*}{$\begin{array}{c}\text { Jumlah } \\
\text { Sampel } \\
(\mathbf{N})\end{array}$} & \multicolumn{2}{|c|}{$\begin{array}{c}\text { Tidak Memakai } \\
\text { Helm }\end{array}$} & \multicolumn{2}{|c|}{$\begin{array}{l}\text { Memakai Helm tapi } \\
\text { Tidak Secara Benar }\end{array}$} & \multicolumn{2}{|c|}{$\begin{array}{l}\text { Memakai Helm } \\
\text { Secara Benar }\end{array}$} \\
\hline & & Jumlah & Proporsi & Jumlah & Proporsi & Jumlah & Proporsi \\
\hline Pengendara SMA & 694 & 6 & $1 \%$ & 170 & $24 \%$ & 518 & $75 \%$ \\
\hline Penumpang SMA & 1942 & 312 & $16 \%$ & 978 & $50 \%$ & 652 & $34 \%$ \\
\hline Penumpang SMP & 2100 & 693 & $33 \%$ & 686 & $33 \%$ & 721 & $34 \%$ \\
\hline Penumpang SD & 1139 & 651 & $57 \%$ & 205 & $18 \%$ & 283 & $25 \%$ \\
\hline Penumpang TK/Balita & 257 & 190 & $74 \%$ & 42 & $16 \%$ & 25 & $10 \%$ \\
\hline Total Pesepeda Motor & 6132 & 1852 & $30 \%$ & 2081 & $34 \%$ & 2199 & $36 \%$ \\
\hline Total Penumpang & 5438 & 1846 & $34 \%$ & 1911 & $35 \%$ & 1681 & $31 \%$ \\
\hline
\end{tabular}

Tabel 5. Jumlah dan proporsi pemakaian helm pada pesepeda motor anak-anak saat jam pulang sekolah

\begin{tabular}{|c|c|c|c|c|c|c|c|}
\hline \multirow[t]{2}{*}{ Golongan } & \multirow{2}{*}{$\begin{array}{c}\text { Jumlah } \\
\text { Sampel } \\
(\mathbf{N})\end{array}$} & \multicolumn{2}{|c|}{$\begin{array}{c}\text { Tidak Memakai } \\
\text { Helm }\end{array}$} & \multicolumn{2}{|c|}{$\begin{array}{l}\text { Memakai Helm tapi } \\
\text { Tidak Secara Benar }\end{array}$} & \multicolumn{2}{|c|}{$\begin{array}{l}\text { Memakai Helm } \\
\text { Secara Benar }\end{array}$} \\
\hline & & Jumlah & Proporsi & Jumlah & Proporsi & Jumlah & Proporsi \\
\hline Pengendara SMA & 559 & 14 & $3 \%$ & 134 & $24 \%$ & 411 & $74 \%$ \\
\hline Penumpang SMA & 671 & 17 & $3 \%$ & 80 & $12 \%$ & 574 & $86 \%$ \\
\hline Penumpang SMP & 324 & 48 & $15 \%$ & 85 & $26 \%$ & 191 & $59 \%$ \\
\hline Penumpang SD & 482 & 218 & $45 \%$ & 72 & $15 \%$ & 192 & $40 \%$ \\
\hline Penumpang TK/Balita & 323 & 183 & $57 \%$ & 21 & $7 \%$ & 119 & $37 \%$ \\
\hline Total Pesepeda Motor & 2359 & 480 & $20 \%$ & 392 & $17 \%$ & 1487 & $63 \%$ \\
\hline Total Penumpang & 1800 & 466 & $26 \%$ & 258 & $14 \%$ & 1076 & $60 \%$ \\
\hline
\end{tabular}

Hasil analisis menunjukkan bahwa tingkat pemakaian helm secara benar pada pengendara sepeda motor usia SMA mencapai 75\% (N=694) saat jam berangkat sekolah dan $74 \%$ $(\mathrm{N}=559)$ saat jam pulang sekolah. Sementara tingkat pemakaian helm secara benar pada penumpang sepeda motor usia SMA saat jam berangkat sekolah hanya sekitar $34 \%$ $(\mathrm{N}=1942)$, namun saat jam pulang sekolah mencapai 86\% $(\mathrm{N}=671)$.

Tingkat pemakaian helm secara benar pada penumpang sepeda motor usia SMP, SD, dan TK/Balita ternyata lebih rendah dibanding penumpang SMA. Tingkat pemakaian helm pada penumpang usia SMP, SD, dan TK/Balita (secara berturutan) saat jam berangkat sekolah hanya mencapai $34 \%$, 25\%, dan $10 \%$ saja. Sementara tingkat pemakaian helm secara benar saat jam pulang sekolah masing-masing sebesar 59\%, 40\%, dan 37\% untuk penumpang usia SMP, SD, dan TK/Balita. 


\section{Hubungan antara Tingkat Pemakaian Helm dan Keparahan Kecelakaan Pesepeda Motor Anak-anak}

Tabel 6 menampilkan perbandingan antara tingkat pemakaian helm secara benar pada anak-anak dan dewasa dengan tingkat keparahan kecelakaan yang dialami keduanya. Data tingkat pemakaian helm secara benar pada pesepeda motor anak-anak didapat dari hasil survey sesuai yang ditampilkan pada Tabel 4 dan Tabel 5, sementara data tingkat keparahan kecelakaan didapatkan dari hasil analisis data korban kecelakaan seperti yang ditampilkan pada Tabel 3. Data tingkat pemakaian helm secara benar pada pesepeda motor dewasa diambil dari studi yang dilakukan oleh John Hopkins International Injury Research Unit (BIGRS, 2018).

Tabel 6. Perbandingan tingkat pemakaian helm secara benar dan tingkat keparahan kecelakaan pada penumpang anak-anak dan dewasa

\begin{tabular}{ccccc}
\hline \multirow{2}{*}{$\begin{array}{c}\text { Kategori } \\
\text { Usia }\end{array}$} & \multicolumn{2}{c}{ Tingkat Pemakaian Helm secara Benar } & \multicolumn{2}{c}{ Tingkat Keparahan Kecelakaan } \\
\cline { 2 - 5 } & Jam Berangkat Sekolah & Jam Pulang Sekolah & Meninggal Dunia & Luka-Luka \\
\hline Anak & $31 \%$ & $60 \%$ & 0,06 & 0,35 \\
\hline Dewasa & & & 0,02 & 0,16 \\
\hline
\end{tabular}

Dari tabel tersebut dapat dilihat bahwa terdapat hubungan antara rendahnya tingkat pemakaian helm secara benar pada penumpang sepeda motor anak-anak (rata-rata 45\%) dengan tingkat keparahan kecelakaan yang dialami. Jika dibandingkan dengan penumpang sepeda motor dewasa, tingkat keparahan kecelakaan meninggal dunia untuk penumpang sepeda motor anak-anak adalah sebesar 3 kali lebih tinggi dibanding penumpang sepeda motor dewasa, sementara tingkat keparahan kecelakaan luka-luka untuk penumpang sepeda motor anak-anak adalah sebesar 2,2 kali lebih tinggi dibanding penumpang sepeda motor anak-anak.

Perbandingan serupa untuk pengendara anak-anak dan dewasa disampaikan pada Tabel 7 berikut.

Tabel 7. Perbandingan tingkat pemakaian helm secara benar dan tingkat keparahan kecelakaan pada pengendara anak-anak dan dewasa

\begin{tabular}{|c|c|c|c|c|}
\hline \multirow{2}{*}{$\begin{array}{c}\text { Kategori } \\
\text { Usia }\end{array}$} & \multicolumn{2}{|c|}{ Tingkat Pemakaian Helm secara Benar } & \multicolumn{2}{|c|}{ Tingkat Keparahan Kecelakaan } \\
\hline & Jam Berangkat Sekolah & Jam Pulang Sekolah & Meninggal Dunia & Luka-Luka \\
\hline Anak & $75 \%$ & $74 \%$ & 0,06 & 0,28 \\
\hline Dewasa & \multicolumn{2}{|c|}{$68 \%$} & 0,13 & 0,42 \\
\hline
\end{tabular}

Tabel 7 mengindikasikan adanya perbedaan pola antara hubungan tingkat pemakaian helm secara benar dengan tingkat keparahan kecelakaan yang dialami pengendara sepeda motor anak-anak dan dewasa dengan penumpang sepeda motor anak-anak dan dewasa. Jika dibandingkan dengan pengendara sepeda motor dewasa, tingkat keparahan kecelakaan meninggal dunia untuk pengendara sepeda motor anak-anak adalah sebesar 0,46 kali lebih rendah dibanding pengendara sepeda motor dewasa, sementara tingkat keparahan kecelakaan luka-luka untuk pengendara sepeda motor anak-anak adalah sebesar 0,67 kali lebih rendah dibanding pengendara sepeda motor dewasa. 


\section{DISKUSI}

Hasil analisis yang telah dilakukan mengindikasikan adanya hubungan antara tingkat pemakaian helm secara benar pada pesepeda motor anak-anak dengan tingkat keparahan kecelakaan yang dialami. Semakin tinggi tingkat pemakaian helm secara benar berhubungan dengan semakin rendahnya risiko mengalami kematian dan luka-luka dalam suatu kecelakaan. Penumpang sepeda motor anak-anak memiliki risiko meninggal dunia 3 kali lebih tinggi dan risiko luka-luka 2,2 kali lebih tinggi apabila mengalami kecelakaan dibanding penumpang sepeda motor dewasa karena tingkat pemakaian helm secara benar pada penumpang sepeda motor anak-anak rata-rata lebih rendah $8 \%$ dibanding penumpang sepeda motor dewasa. Pengendara sepeda motor anak-anak memiliki risiko meninggal dunia 0,46 kali lebih rendah dan risiko luka-luka 0,67 kali lebih rendah apabila mengalami kecelakaan dibanding penumpang sepeda motor dewasa karena tingkat pemakaian helm secara benar pada pengendara sepeda motor anak-anak rata-rata lebih tinggi $7 \%$ dibanding pengendara sepeda motor dewasa.

Tingkat pemakaian helm secara benar pada penumpang anak-anak $(45 \%)$ rata-rata lebih rendah dibanding penumpang dewasa (53\%), namun tingkat pemakaian helm secara benar pada pengendara anak-anak $(75 \%)$ rata-rata lebih tinggi dibanding penumpang dewasa (68\%). Dengan catatan, pengendara anak-anak yang ditinjau disini hanya pengendara usia SMA. Tingkat pemakaian helm secara benar pada penumpang anak-anak lebih tinggi pada jam pulang sekolah (60\%) dibanding jam berangkat sekolah (31\%). Kemungkinan penyebabnya adalah lebih longgarnya penegakan hukum saat jam berangkat sekolah dibanding jam pulang sekolah. Kemungkinan lain adalah penggunaan ojek online saat pulang sekolah, dimana pengendara ojek online umumnya mewajibkan penumpangnya mengenakan helm. Hal lain yang diamati saat survey adalah semakin tinggi usia anakanak, maka semakin tinggi juga tingkat pemakaian helmnya. Hasil studi Save the Children (2015) menyebutkan alasan utama anak-anak usia SD tidak memakai helm saat diantar/dijemput ke/dari sekolah adalah tidak punya helm dan jarak yang dekat antara rumah dan sekolah. Sementara untuk anak-anak usia SMP alasan utamanya adalah tidak pernah disuruh memakai helm dan jarak yang dekat antara rumah dan sekolah.

Hasil analisis data kecelakaan menunjukkan bahwa sebanyak $56 \%$ pesepeda motor korban kecelakaan tidak diketahui apakah memakai helm atau tidak sehingga dapat menyebabkan biasnya hasil analisis yang telah dilakukan. Lebih lanjut, ternyata terdapat 21 anak-anak yang masih berusia dibawah 15 tahun (kategori SD dan SMP) yang menjadi pengendara sepeda motor meskipun belum cukup umur. Hal ini merupakan temuan penting yang harus menjadi bahan bagi para orang tua dan pemangku kepentingan untuk memperketat pengawasan terhadap penggunaan kendaraan sepeda motor.

\section{KESIMPULAN DAN REKOMENDASI}

Terdapat hubungan antara tingkat pemakaian helm secara benar pada pesepeda motor anak-anak dengan tingkat keparahan kecelakaan yang dialami. Semakin tinggi tingkat pemakaian helm secara benar berhubungan dengan semakin rendahnya risiko mengalami kematian dan luka-luka dalam suatu kecelakaan. Penumpang sepeda motor anak-anak memiliki risiko meninggal dunia 3 kali lebih tinggi dan risiko luka-luka 2,2 kali lebih tinggi apabila mengalami kecelakaan dibanding penumpang sepeda motor dewasa karena tingkat pemakaian helm secara benar pada penumpang sepeda motor anak-anak rata-rata 
lebih rendah $8 \%$ dibanding penumpang sepeda motor dewasa. Pengendara sepeda motor anak-anak memiliki risiko meninggal dunia 0,46 kali lebih rendah dan risiko luka-luka 0,67 kali lebih rendah apabila mengalami kecelakaan dibanding penumpang sepeda motor dewasa karena tingkat pemakaian helm secara benar pada pengendara sepeda motor anakanak rata-rata lebih tinggi $7 \%$ dibanding pengendara sepeda motor dewasa.

Mengingat masih rendahnya tingkat pemakaian helm pada anak-anak, terutama saat jam berangkat sekolah, diharapkan dapat dilakukan upaya pendidikan/sosialisasi untuk anakanak usia sekolah dan orang tuanya akan pentingnya mengenakan helm secara benar serta memperketat penegakan hukum terhadap anak-anak yang tidak mengenakan helm saat menjadi penumpang sepeda motor. Diharapkan pula untuk dapat dilakukan pencatatan secara lebih lengkap pada laporan kecelakaan terhadap aspek pemakaian helm dari para korban kecelakaan sepeda motor, sehingga penelitian yang lebih komprehensif dapat dilakukan.

\section{UCAPAN TERIMA KASIH}

Penulis berterimakasih kepada Traffic Accident Research Center (TARC) Korlantas Polri yang telah memberi dana untuk mendukung penelitian ini, dan juga kepada Kasatlantas Polrestabes Bandung (AKBP Agung Reza Pratidina, S.I.K.), Wakasatlantas Polrestabes Bandung (Kompol Bayu Catur Prabowo), Kanit Dikyasa Satlantas Polrestabes Bandung (AKP Nurindah), dan Kanit Laka Satlantas Polrestabes Bandung (AKP Hendra Hasibuan) yang telah memberikan dukungan data untuk melakukan penelitian ini.

\section{DAFTAR PUSTAKA}

Abbas, A.K., Hefny, A.F., dan Abu-Zidan, F.M. 2009. Does Wearing Helmets Reduce Motorcycle-related Death? A Global Evaluation. Accident Analysis and Prevention, vol. 49, hal. $249-252$.

BIGRS. 2018. Risky Road Behaviors in Bandung, September 2017. Bandung - Indonesia, John Hopkins International Injury Research Unit (JHIIRU) - Universitas Padjadjaran (Unpad).

BIGRS. 2017. Data Technical Report - Round 6, August 2017. Bandung - Indonesia, John Hopkins International Injury Research Unit (JHIIRU) - Universitas Padjadjaran (Unpad).

Dandona, R., Kumar, G.A., Raj, T.S., dan Dandona, L., 2006. Patterns of Road Traffic Injuries in a Vulnerable Population in Hyderabad, India. Injury Prevention, vol. 12, hal $183-188$.

Kelly, P., Sanson, T., Strange, G., dan Orsay, E., 1991. A Prospective Study of the Impact of Helmet Usage on Motorcycle Trauma. Annual Emergency Medicine, vol. 20, hal $852-856$.

Lin, M.R. dan Kraus, J.F. 2009. A Review of Risk Factors and Patterns of Motorcycle Injuries. Accident Analysis and Prevention, vol. 41, hal. 710 - 719.

Pemerintah Kota Bandung. 2017. Bandung Road Safety Annual Report 2015 - 2016.

Pemerintah Kota Bandung. 2018. Bandung Road Safety Annual Report 2017.

Save the Children 2015. Studi Baseline Keselamatan Sisi Jalan. 
Shankar, B.S., Ramzy, A.I., Soderstrom, C.A., Dischinger, P.C., dan Clark, C.C., 1992. Helmet Use, Patterns of Injury, Medical Outcome, and Costs among Motorcycle Drivers in Maryland. Accident Analaysis and Prevention, vol. 24, hal 385 - 396.

Servadei, F., Begliomini, C., Gardini, E., Giustini, M., Taggi, F., dan Kraus, J., 2003. Effect of Italy's Motorcycle Helmet Law on Traumatic Brain Injuries. Injury Prevention, vol. 9, hal $257-260$.

WHO. 2016. Global Road Safety Status Report 2015. 